Originality. In the process of pedagogical practice, the main directions of pedagogical activity are considered: pedagogical, research, cultural and educational, project. The ways of improving the pedagogical practice in the context of the formation of the methodological competence of future teachers of geography are determined.

Conclusion. Thus, pedagogical practice creates conditions that require the trainee to mobilize all the knowledge and skills obtained at the university, their use is integrated taking into account specific goals and conditions of study. It is also an indispensable school for forming a teacher, the results of which depend on the stu- dents' understanding of the goals and objectives of the practice, the ability to fully and correctly combine various areas of pedagogical activity in a single educational process and the ability to conduct research work of a professional and pedagogical nature.

Keywords: future teacher of geography; competence-based approach; innovative technologies; teaching practice; geography.

Одержано редакиією 15.01.2019 Прийнято до публікаиї̈ 24.01.2019

DOI $10.31651 / 2524-2660-2019-2-62-67$

ORCID 0000-0002-0656-2413

DANYLYUK Serhiy,

Doctor in Pedagogy, Professor,

Chair of Higher School Pedagogy and Educational Management Department, Bohdan Khmelnytsky National University at Cherkasy,

e-mail: sedan@bigmir.net

UDC 378.091.12 : 364 - 051 (045)

\title{
IMPLEMENTATION OF MANAGERS' PROFESSIONAL-AND-MANAGERIAL ORIENTATION IN THE PROCESS OF SOCIO-CULTURAL ACTIVITIES
}

\begin{abstract}
Introduction. The phenomenon of implementation of managers' professional-andmanagerial orientation in the process of sociocultural activities is studied in the paper. A group of factors which support the expectations of implementation of professional-and-managerial orientation in the profession is given: increase of professional status and social-and-legal protection; provision of guarantees of the implementation of the qualification obtained; creation of optimal working conditions; the possibility of improving living conditions; decent wages.
\end{abstract}

Purpose. Substantiate theoretically the content and specific features of the phenomenon of implementation of managers' professional-and-managerial orientation in the process of socio-cultural activities.

Results. Socio-cultural activities can be considered in two plans: 1) in a broad sense - as a way of a person's being, as a system of inherited experience, as a material and spiritual environment conducive to a person's formation and elevation; 2) in a narrow sense - as a specific form of people's life, including the preservation and use of cultural-and-historical heritage (museum, library, archival business, national and local traditions), art education, creativity, leisure and entertainment, amateur, ethnography, crafts, and also providing a form (Management, Economics, Computer Science, specialists' training and retraining) and the formation of their professional orientation as $o b$ jects and subjects of socio-cultural activities.

Structurally, socio-cultural activities, according to scientists, takes place in three main directions: 1) economic, where the predominant place in the characteristics of socio-cultural activities is occupied by such categories as cost accounting and profitability, costs and development of investments, efficiency, selfsufficiency, material security; 2) humanitarian, covering a wide range of content and modern technologies of socio-cultural activities, which includes a whole block of initial concepts of social work, leisure, sociocultural sphere, social purpose, principles and functions, private and industry-specific methods, domestic and foreign experience; 3) organizational-and- managerial, where the basis of semantic structures is formed by the concepts of management in the sociocultural sphere, centralization and decentralization, democracy and self-government, control and reporting, socio-cultural diagnostics, forecasting and design.

According to the basic idea of the theory of systems, an integral socio-cultural system consists of a set of elements that are combined by various interrelations. It is a generalized, summary result of the state of such many social and cultural components, as the final elements (people's active and mass culture creating activity); interrelations of elements (sociocultural relations, interpersonal relations, cultural exchanges, interactions, communication, etc.); functions of elements of the system as a whole (the need of certain cultural-and-normative actions to preserve the culture); boundaries (increased opportunities for people to be included in cultural processes); subsystems (the number of groups of amateur creativity, amateur associations and clubs of interests and other club formations); environment (creation of conditions for cultural activities, interaction with neighboring socio-cultural systems).

Conclusion. Consequently, science, education and practice are organically represented in the structure of socio-cultural activities. The subject field of this new science has a rich background associated with cultural-and-educational work, and new trends aimed at scientific, educational and practical activities: cultural-and-leisure activities, Social Pedagogy, Culture Sociology, Applied Cultural Studies, etc.

Keywords: socio-cultural sphere, sociocultural activities, professional-and-managerial orientation, management of socio-cultural activities.

The process of formation and development of professional-and-managerial orientation of managers of socio-cultural activities is carried out continuously throughout the entire life cycle of professional activities. Professional orientation, regardless of the nature of the profession, has no definitive limits 
in its completion. The specificity of working conditions and the scope of activities of managers of socio-cultural activities forms a special psychological repository of the personality of this profession, whose views and perceptions are largely developed thanks to the experience gained, perception, expectations, forecasts and perspectives.

Professional orientation connects a person not only with the profession, but also with the whole world. In the structure of this process, an important role is played by meanings, specific situations and generally speaking the acquired experience. Professional orientation as a subjective state of an individual can be changed in accordance with the needs that have arisen, a specialist's tasks, his/her goals, and value concepts influenced by professional activities.

The problem of professional training of future managers of socio-cultural activities was the subject of scientific research of a whole cohort of researchers [1-10].

The starting point for the implementation of the professional orientation of a manager of socio-cultural activities is the professional-and-managerial process in the sociocultural sphere, where a specialist can realize himself as a person, showing his professional qualities as a proof of his/her professionally-oriented consistency.

Besides, in a real professional process, the professional stability of a manager of socio-cultural activities grows, which ensures a reduction in turnover, an increase in a specialist's status and prestige. The implementation of professional-andmanagerial orientation, therefore, is due to its development, which is supported by such factors of the expectations of implementation in the profession, as:

- increase of professional status and social-and-legal protection;

- provision of guarantees of the implementation of the qualification obtained;

- creation of optimal working conditions;

- the possibility of improving living conditions;

- decent wages.

Professional activities of managers of socio-cultural activities are thus the most important factor in the implementation and development of their professional-andmanagerial orientation, and socio-cultural activities are the subject of the imple?entation of the professional orientation of this specialist.
The development of market relations in sociocultural activities largely changed the mission, goals and tasks of its functioning, updated management methods and principles. Dynamic processes of labor division, manifested in the renewal of modern specialists' social functions, roles and statuses, have deepened their specialization in various areas of sociocultural activities: managerial, intellectual, artistic, cultural-and-creative, leisure, communicative, etc. Today the tendency to deepen the specialization of various directions of activities has objectively become an important factor in the overall sociocultural progress.

In socio-cultural activities in the process of labor division, culture, education, leisure culture, social pedagogy, etc. are of key importance. In other words, these are the areas of activities that are the closest to a person, his/her spiritual, moral, artistic development, his/her social health and social protection.

Culture is a product of the collective activities of people, and its practical creators and performers are individuals. Traditionally, each individual acts in relation to culture at the same time in several guises: as a "product" of culture, introduced into its norms and values, trained in activity technologies, ethics of interrelationships with other people in the process of its inculturation and socialization, carried out during child upbringing, upon getting general and special education, in the process of contacts with the social environment.

Inculturation is the process of introducing an individual to a culture, mastering essential habits, norms, and patterns of behavior by him/her. In Oxford Illustrated Encyclopedia, socialization is interpreted as a complex process of assimilation of the system of knowledge, norms and values by an individual that allow him to function in society [11, p. 270].

In socio-cultural activities, inculturation and socialization are a two-pronged process - familiarizing an individual with culture, assimilating and active reproducing of social experience (cultural, social norms, values, behavior patterns, roles, attitudes, customs, cultural traditions, etc.). Here an individual acts as a "consumer" of culture, since he/she uses norms and rules of the culture he/she has learned in his/her social and professional practice; but at the same time - 
also as a "producer" of culture, because he/she creatively generates new cultural forms, and also as a "translator" of culture, since he/she reproduces cultural patterns in his/her practical actions and judgments.

Of course, the theoretical value and practical significance of each science is mainly determined by the level of elaboration of concepts in which the subject, goals, tasks, patterns, functionality and viability of practical outputs are revealed. Otherwise, the cognitive thinking and the content that has been incorporated into it turn out to be mismatched, disordered, and without obligation. Considering the notion of "concept" as a system of explanation, extending to still unsolved tasks within a specific subject field, we present the scientific concept of socio-cultural activities as an area of knowledge which is internally organized, consciously ordered, built into the system. Having a certain, but not unlimited, subject field of external and internal facts and experience, the concept of socio-cultural activities in the process of its conceptualization registers, fixes, orderly describes and classifies everything that occurs in this field of facts and experience. Moreover, it potentially self-critically assesses itself (reflection) and due to this is predisposed to a dialogue with concepts of other sciences, without claiming to be a complete monopoly.

Socio-cultural activities are characterized as a definite system of ideas, reflecting the goals and functions of state social policy in the field of culture and leisure, defining ways, methods and means of their implementation in conditions of reform processes of socio-economic and social life which take place in the country.

Consequently, science, education and practice are organically represented in the structure of socio-cultural activities. The subject field of this new science has a rich background associated with cultural-andeducational work, and new trends aimed at scientific, educational and practical activities: cultural-and-leisure activities, Social Pedagogy, Culture Sociology, Applied Cultural Studies, etc.

The concept of "socio-cultural activities", due to a wide range of problems within it, does not have an unambiguous interpretation, but each of the existing concepts enriches this multidimensional phenomenon with new facets and aspects, like a multivalued interpretation of the concept "culture".

The term "sociocultural activities" is associated with the concept of "cultural activities" and is interpreted as an activity of identifying, preserving, shaping, disseminating and mastering of cultural values.

Socio-cultural activities can be considered in two plans:

- in a broad sense - as a way of a person's being, as a system of inherited experience, as a material and spiritual environment conducive to a person's formation and elevation;

- in a narrow sense - as a specific form of people's life, including the preservation and use of cultural-and-historical heritage (museum, library, archival business, national and local traditions), art education, creativity, leisure and entertainment, amateur, ethnography, crafts, and also providing a form (Management, Economics, Computer Science, specialists' training and retraining) and the formation of their professional orientation as objects and subjects of socio-cultural activities.

The etymology of the concept "sociocultural activities" initially presupposes the activity character of the processes taking place in this area, in which professional orientation is developed.

Structurally, these activities, according to scientists, takes place in three main directions [12]:

- economic, where the predominant place in the characteristics of socio-cultural activities is occupied by such categories as cost accounting and profitability, costs and development of investments, efficiency, selfsufficiency, material security;

- humanitarian, covering a wide range of content and modern technologies of sociocultural activities, which includes a whole block of initial concepts of social work, leisure, socio-cultural sphere, social purpose, principles and functions, private and industry-specific methods, domestic and foreign experience;

- organizational-and-managerial, where the basis of semantic structures is formed by the concepts of management in the sociocultural sphere, centralization and decentralization, democracy and selfgovernment, control and reporting, sociocultural diagnostics, forecasting and design.

A common specific feature of objects of a manager's activity in the socio-cultural 
sphere, in our opinion, is the high level of systematicity of these objects. In other words, the object of a manager's activity is a complete complex open system, in which a manager's transformative and cognitive activity can and should cover both an entire system (an object) as a whole, and its individual elements (individual aspects of an object - teams, institutions and organizations). At the same time, a manager's professionally directed activity should take into account the maximum of an object's system connections, both in-system and with other objects (systems). In our opinion, this is one of the characteristic features of a professionally oriented managerial activity in the socio-cultural sphere.

According to the basic idea of the theory of systems, an integral socio-cultural system consists of a set of elements that are combined by various interrelations. It is a generalized, summary result of the state of such many social and cultural components, as the final elements (people's active and mass culture creating activity); interrelations of elements (sociocultural relations, interpersonal relations, cultural exchanges, interactions, communication, etc.); functions of elements of the system as a whole (the need of certain cultural-and-normative actions to preserve the culture); boundaries (increased opportunities for people to be included in cultural processes); subsystems (the number of groups of amateur creativity, amateur associations and clubs of interests and other club formations); environment (creation of conditions for cultural activities, interaction with neighboring socio-cultural systems) [13, p. 47].

Based on this, it can be concluded that it is the specificity of the object of activities that determines both the content of the subject-and-practical activity of a manager of socio-cultural activities, and the character of the implementation of his/her professional orientation.

A wide profile of professionally directed aspirations of a manager of socio-cultural activities is realized at the level of mastering the types of activities characteristic of the whole cycle of its interaction with the objectsystem. In this case, psychologists use the term "type of orientation". A manager as a specialist with a high type of orientation in his professionally oriented activities does not have great difficulties in transferring (if necessary) the main activities to other subject areas previously unknown to him.

Examples are typical when graduates of establishments of higher education of culture and arts, prepared for activities in establishments of culture, after a short adaptation, successfully work in the sphere of tourism, film production and rental, touring-and-concert activities, office management, etc. A wide range of professionally directed interests of a manager of socio-cultural activities, meanwhile, does not mean the vagueness of his/her qualifications, ability and readiness to solve a fairly narrow and specific type of tasks without additional adaptation.

The implementation of the professional orientation of a manager of socio-cultural activities is ensured, in our opinion, by the optimal ratio of general and specific types of solved professional tasks, the level of sustainability of the professional orientation formed by establishments of higher education, in accordance with the goals set by the customer (the state, institutions and organizations), and also traditions of fundamental professional training chara?teristic of establishments of higher education of culture and arts.

The effective implementation of the professional orientation of a manager of sociocultural activities is determined by such a general philosophical concept as "activity". The object-activity approach in socio-cultural activities becomes the cornerstone of the implementation of a manager's professionally directed position, his/her ability to realize himself/herself in an integrated system that is the object of activities, to determine the cycle of interaction with it, the activities characteristic of different stages of this cycle, types of professional tasks for each stage, the place of the direct object of activities in the overall structure of the system, as well as socio-political, economic, environmental, etc. aspects of a specialist's activities that ensure the functioning of this and other systems connected with it.

Activity is a specifically human form of active relation to the world around us, the content of which is the expedient change and transformation of this world on the basis of the development of existing forms of culture. The nature of activities is determined by the complex interaction of the goal, means and result of activities. Based on this provision, it can be determined that sociocultural selforganization and social-and-normative activities, as two parallel but interrelated processes, imply a certain organization of activities, to a greater or lesser extent, present in both processes.

In the definition of "organization" the scientists' opinion is ambiguous. Considering "organization" in connection 
with activities of establishments of culture, which fills this concept with living meanings, researchers see this problem from different perspectives. A. D. Zharkov believes that the organization of activities of establishments of culture requires specialists to be able to distribute work, define personal duties, rights and responsibilities, set the time to complete work, develop a system of monitoring the implementation of decisions made, conduct things in order to see and solve fundamental issues in perspective. An organization is constantly intended to ensure an optimal state of the club as a social-and-pedagogical system, i.e. coherence, interaction, subordination and coordination of all its structural elements. Attention is also focused on the character of organizational-and-managerial decisions in the activities of establishments of culture [14].

As it can be seen, researchers consider the essence of the organization of the activities of institutions from different positions. Of course, in each position there is a rational grain that deserves attention.

However, almost all authors stand on the positions of a rigid model of organizing the activities of establishments of culture, in which there is no room for socio-cultural self-organization, because all activities are based on a social-and-normative vertical scheme. From the variety of interpretations and definitions of the term "organization of activities" we would like to highlight the definition, where "organization" is represented as a system of interrelated elements - subjects, objects, orderliness and activity. However, this definition is of a general nature and does not reflect the essence of any particular process, especially the activities of establishments of culture and the forms of its organization.

The "organization of activities" of establishments of culture is a process of achieving goals using such means and methods of cultural policy that comply with the principles of an individual's sociocultural self-organization and social-andnormative identification. It is not by chance that we paid quite a lot of attention to the issue of organizing the activities of establishments of culture, for we consider it to be important in understanding their dual function.

The phenomenon of duality in the activities of establishments of culture is not their "invention", it is associated with the polyphonic nature of the socio-cultural activity itself, which, from the point of view of researchers, can be considered as a technology (a mode of human activity) and in the personal aspect of human existence dominated by "essential human powers", "creativity", "spiritual wealth".

Despite the external opposite of the "technological" and "personal". approaches, it is impossible not to see in them the dialectical unity. The "technological" approach is associated with "processing nature by people" and is manifested in the social-and-normative functions of estab?ishments of culture, and "personal" "processing people by people" - with the function of an individual's socio-cultural selforganization.

\section{References}

1. Bryl, M. M. (2018). Manager of Socio-Cultural Activities as a Subject of Innovations. Bulletin of Kiev National University of Culture and Arts. Series: Management of Socio-cultural activities. 1. 41-52.

2. Karlova, V.V. (2017). Training of Managers of the Sphere of Culture to Professional Activities in the Conditions of Formation of Market Relations in Ukraine: Directions and Perspectives. Scientific Notes of V. I. Vernadsky Tavria National University. Series: Public Administration. Vol. 28 (67), 1. 33-39.

3. Kostyuchenko, O.V. (2017). Creative and Adaptive Potential of Teaching Managers of the SocioCultural Sphere. Scientific Bulletin of Kherson State University. Series: Psychological Sciences. 3, 2. 36-40.

4. Kravchenko, L.M., Yaremaka, N.S. (2017). Pedagogical Model of Formation of Information Competence of Future Managers of the Leisure Industry. Young Scientist. 8.1 (48.1). 18-21.

5. Lokshin, V.S. (2010). Formation of Professional Competence of Future Managers of the SocioCultural Sphere in Higher Educational Establishments. Native school. 11 (November). 45-49.

6. Lokshin, V.S. (2011). Professional Competence of Managers of the Socio-Cultural Sphere in the Context of Phenomenological Components of the Conceptual Apparatus. Youth and Market. 1 (72). 59-65.

7. Lokshin, V.S. (2011).Psychological-and-Pedagogical Bases of Training of Future Managers of the SocioCultural Sphere on the Basis of Competence Approach. Youth and Market. 8 (79). 51-54.

8. Lokshin, V.S. (2013). Formation of Leadership Qualities of Future Managers of Socio-Cultural Activities in the Context of the Process of Modernization of Higher Education. Spirituality of the Personality: Methodology, Theory and Practice. 1 (53). 109-120.

9. Nagayev, V.M. (2017). Formation of the Experience of Managers' Socio-Cultural Professional Communication in the Process of Their Professional Training. Actual Problems of Innovative Economy. 2. 42-47.

10. Petrova, I.V. (2015). Professional Training of Managers of Leisure Industry in Modern Society. Bulletin of Mariupol State University. Series: Philosophy, Culturology, Sociology. 9. 117-124.

11. Oxford Illustrated Encyclopedia (2000). 9 volumes: Transl. from English. Moscow. INFRA-M, Whole World. V. 7: Peoples and culture.

12. Kyselyova, T.G., Krasylnykov, Yu.D. (1995). Fundamentals of Socio-Cultural Activities. Moscow. MSUCA.

13. Chyzhykov, V.M., Chyzhykov, V.V. (2003). Introduction to Socio-Cultural Management. Moscow. MSUCA.

14. Zharkov, A.D. (2002). Technology of Cultural and Leisure Activities. Moscow. MSUCA. 


\section{Список бібціографічних посимань}

1. Бриль М.М. Менеджер соціокультурної діяльності як суб'єкт інновацій. Вісник Київського національного університету культури і мистеитв. Сeрія: Менеджмент соиіокультурної діяльності. 2018. 1. C. 41-52.

2. Карлова В.В. Підготовка менеджерів сфери куцьтури до професійної діяльності в умовах становмення ринкових відносин в Україні: напрями та перспективи. Вчені записки ТНУ імені В. I. Вернадського. Серія: Державне управління. 2017. 28 (67), 1. 33-39.

3. Костюченко О.В. Творчий і адаптивний потенціал навчання менеджерів соціокультурної сфери. Науковий вісник Херсонського державного університету. Серія: Психологічні науки. 2017. 3, 2. 36-40.

4. Кравченко М.М., Яремака Н.С. Педагогічна модель формування інформаційної компетентності майбутніх менеджерів індустрії дозвімля. Молодий вчений. 2017. 8.1 (48.1). 18-21.

5. Мокшин В.С. Формування професійної компетентності майбутніх менеджерів соціокультурної сфери у ВНЗ. Рідна школа. 2010. 11. 45-49.

6. Мокшин В.С. Професійна компетентність менеджерів соціокультурної сфери в контексті феноменологічних складових понятійного апарату. Молодъ $i$ ринок. 2011. 1 (72). 59-65
7. Мокшин В.С. Психолого-педагогічні основи підготовки майбутніх менеджерів соціокультурної сфери на основі компетентнісного підходу. Молодъ і ринок. 2011.8 (79). 51-54.

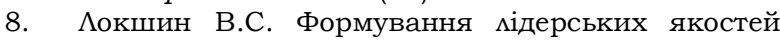
майбутніх менеджерів соціокультурної діяльності в контексті процесу модернізації вищої освіти. Духовність особистості: методологія, теорія $i$ практика. 2013. 1(53). 109-120.

9. Нагаєв В.М. Формування досвіду соціокультурної професійної комунікації менеджерів у процесі іх фахової підготовки. Актуальні проблеми інноваиійної економіки. 2017. 2. 42-47.

10. Петрова I.В. Професійна підготовка менеджерів індустрії дозвілля в сучасному суспільстві. Вісник Маріупольського державного університету. Сeрія: Філософія, культурологія, соиіологія. 2015. 9. 117-124.

11. Оксфордская иллюстрированная энииклопедия: в 9 т. : пер. с англ. М.: ИНФРА-М, Весь Мир. 2000. [Т. 7]: Народы и культура.

12. Киселёва Т.Г., Красильников Ю.Д. Основы соииально-культурной деятельности. М.: МГУКИ. 1995.

13. Чижиков В.М., Чижиков В.В. Введение в соииокультурный менеджмент. М.: МГУКИ. 2003.

14. Жарков А.Д. Технология культурно-досуговой деятельности. М.: МГУКИ. 2002.

ДАницюК Сергій Семенович,

доктор педагогічних наук, професор, завідувач кафедри педагогіки вищої школи і освітнього менеджменту,

Черкаський національний університет імені Богдана Хмельницького

\section{ВПРОВАДЖЕННЯ ПРОФЕСІЙНО-УПРАВАІНСЬКОЇ ОРІСНТАЦІЇ МЕНЕДЖЕРІВ У ПРОЦЕСІ СОЦІААЬНО-КУАЬТУРНОЇ ДІЯИЬНОСТІ}

Анотаиія. Вступ. Досліджено френомен реалізаиї̈ професійно-управлінської орієнтації менеджерів у проиесі соиіокультурної діяльності. Виокремлено групу фракторів, шо підтримують очікування реалізащії професійно-управлінської орієнтації у професії: підвищення професійного статусу та соиіальноправового захисту; забезпечення гарантій використання отриманої квалірікаиії; створення оптимальних умов праці; можливість покращення умов життя; гідна заробітна плата.

Мета. Теоретично обтрунтувати зміст і особливості феномену реалізаиї професійно-управлінської орієнтаиї керівників у процесі соиіокультурної діяльHOCmi.

Результати. Соиіально-культурні заходи можна розглядати у двох планах: 1) у широкому сенсі - як спосіб існування людини, як системи успадкованого досвіду, як матеріального та духовного середовища, шо сприяе формуванню та піднесенню людини; 2) у вузькому сенсі - як спеиифічну форму життя людей, включаючи збереження та використання культурноісторичної спадщини (музей, бібліотека, архівна справа, наиіональні та місиеві традииіi), мистецьку освіmy, творчість, дозвілля та розваги, аматорські, етнографічні, ремісничі, а також надання форми (менеджмент, економіка, інформатика, підготовка і перепідготовка фрахівиів) $i$ формування їх професійної орієнтаиї̈ як об'єктів і суб'єктів соиіально-культурної діяльності.

Структурно соиіально-культурні заходи, на думку вчених, проходять у трьох основних напрямках: 1) економічні, де переважне місие в характеристиках соиіокультурної діяльності займають такі категорії, як облік витрат $і$ прибутковість, витрати і розвиток інвестииій; ефрективність, самодостатність, матеріальна безпека; 2) гуманітарний, шо охоплюе широкий спектр змісту і сучасних технологій соиіально-культурної діяльності, шо включае в себе иілий блок вихідних кониепиій соціальної роботи, дозвілля, соиіокультурної сфери, соиіальних иілей, приниипів $i$ функцій, приватних і галузевих методів, вітчизняний і зарубіжний досвід; 3) організаиійно-управлінсъкий, де основою семантичних структур є кониепиї управління в соиіально-культурній срері, иентралізаиія $i$ деиентралізаиія, демократія $і$ самоврядування, контроль і звітність, соиікультурна діагностика, прогнозування та проектування .

Відповідно до основної ідеї теорії систем, інтегральна соиіокультурна система складається із сукупності елементів, які поєднуються різними взаємозв'язками. Це узагальнений результат стану таких багатьох соиіальних $i$ культурних компонентів, як кіниеві елементи (активна $і$ масова культурна активність людей); взаємозв'язок елементів (соиіокультурні відносини, міжособистісні відносини, культурні обміни, взаємодї̈, спілкування тошо); функиї елементів системи в иілому (необхідність певних культурно-нормативних дій для збереження культури); межі (розширення можливостей для включення людей до культурних проиесів); підсистеми (кількість груп самодіяльної творчості, самодіяльні асоиіації та клуби за інтересами й інші клубні формування); середовище (створення умов для культурної діяльності, взаємодія із сусідніми соиіально-культурними системами).

Висновок. Отже, наука, освіта та практика органічно представлені у структурі соиіокультурної діяльності. Предметна область иієї нової науки має багатий досвід, пов'язаний із культурно-виховною роботою, а також новими напрямками наукової, навчальної та практичної діяльності: культурнодозвіллева діяльність, соиіальна педагогіка, соиіологія культури, прикладна культурологія тощо.

Ключові слова: соиіокультурна сфрера; соиіокультурна діяльність; професійно-управлінська орієнтація; управління сочіокультурною діяльністю.

Одержано редакиією 17.01.2019 Прйнято до публікаиї 21.01.2019 